\title{
FEATURES OF INTERLABORATORY COMPARISON METHODS WHEN MEASURING VIBROACOUSTIC PARAMETERS
}

Sterlikov AV ${ }^{1}$, Kurilenko YuV², Voronkov $A A^{2}$

${ }^{1}$ Research and Technical Center of Radiation-Chemical Safety and Hygiene of Federal Medical-Biological Agency, Moscow, Russia

2 Tsifrovye Pribory Ltd, Moscow, Russia

External quality control in the form of interlaboratory comparisons (ILCs) is an important criterion of the testing laboratory competence. The study was aimed to summarize the approaches to developing objects for proficiency testing (OPT) based on physical simulation of acoustic noise sources, airborne ultrasound, vibration, and the practice of their use for ILC. Analysis of the OPT effectiveness based on physical simulation of factors, the test benches (TBs), was performed based on their testing and certification results, as well as on the results of appropriate ILCs. The results of using TB as OPT are considered for the following factors: acoustic noise, airborne ultrasound, and vibration. When measuring acoustic noise, TB played back the acoustic noise record with high stability. ILC involving measurement of airborne ultrasound was performed the same way, however, the frequency of the acoustic signal being reproduced was in the range of $11-22 \mathrm{kHz}$. TBs, based on a manual mechanized tool and a platform equipped with electromechanical agitator, were developed for ILC involving the measurement of local and general vibration. Stability of vibration generated was provided by means of the automated system for maintaining the set level with feedback and proportional integral derivative (PID) controller. When arranging and performing ILCs involving measurement of noise and vibration, a crucial role is played by the methods developed specifically for ILCs, allowing one to take into account all the conditions that affect the measurement results.

Keywords: interlaboratory comparison, acoustic noise, ultrasound, vibration measurement

Author contribution: all authors contributed to data acquisition, data compilation, and manuscript writing.

$\triangle$ Correspondence should be addressed: Alexander V. Sterlikov

Shchukinskaya, 40, Moscow, 123182; asterlikov@mail.ru

Received: 27.05.2021 Accepted: 11.06.2021 Published online: 18.06.2021

DOI: $10.47183 /$ mes.2021.012

\section{ОСОБЕННОСТИ МЕТОДОВ ПРОВЕДЕНИЯ МЕЖЛАБОРАТОРНЫХ СЛИЧЕНИЙ ПРИ ИЗМЕРЕНИИ ВИБРОАКУСТИЧЕСКИХ ПОКАЗАТЕЛЕЙ}

\author{
А. В. Стерликов ${ }^{1}$, Ю. В. Куриленко ${ }^{2}$ А. А. Воронков ${ }^{2}$ \\ ${ }^{1}$ Научно-технический центр радиационно-химической безопасности и гигиены, Москва, Россия \\ ${ }^{2}$ ООО «ПКФ Цифровые приборы», Москва, Россия
}

\begin{abstract}
Важным критерием компетентности испытательных лабораторий являются результаты внешнего контроля качества в форме межлабораторных сличительных испытаний (МСИ). Целью работы было обобщить подходы к созданию объектов для проверки квалификации (ОПК) на основе физических моделей источников акустического шума, воздушного ультразвука, вибрации и их использования для проведения Мси. Анализ эффективности ОПК на основе физических моделей факторов - испытательных стендов (ИС) производили по результатам их испытаний и аттестации, а также по результатам МСИ с их использованием. Рассмотрены результаты использования ИС в качестве ОПК факторами акустического шума, ультразвука и вибрации. При измерениях акустического шума ИС воспроизводил его запись с высокой стабильностью. Аналогичным образом осуществляли Мси с измерением уровня воздушного ультразвука, но частота воспроизводимого акустического сигнала находилась в диапазоне 11-22 кГц. Для проведения МСИ с измерением локальной и общей вибрации были разработаны ИС на основе ручного механизированного инструмента и платформы с электромеханическим побудителем. Стабильность уровня генерируемой вибрации обеспечивало применение системы автоматизированного поддержания заданного уровня с обратной связью и использованием пропорционально-интегрально-дифференциального регулятора. При организации и проведении МСИ с измерением шума и вибрации значительную роль играют методики, разработанные специально для проведения МСИ и позволяющие учесть все условия, влияющие на результаты измерений.
\end{abstract}

Ключевые слова: межлабораторные сличительные испытания, акустический шум, ультразвук, измерение вибрации

Вклад авторов: все авторы участвовали в сборе экспериментальных данных, их обобщении и подготовке статьи.

$\triangle$ Для корреспонденции: Александр Васильевич Стерликов ул. Щукинская, д. 40, г. Москва, 123182; asterlikov@mail.ru

Статья получена: 27.05.2021 Статья принята к печати: 11.06.2021 Опубликована онлайн: 18.06.2021

DOI: $10.47183 /$ mes.2021.012

The results of external quality control in the form of interlaboratory comparisons (ILCS) are an important criterion of the testing laboratory competence. The need for participation in ILCs is one of the requirements for testing laboratories codified in the law $[1,2]$. Control over compliance with these requirements is exercised by both Rosaccreditation, and executive authorities in charge of accredited organizations $[3,4]$.

Among tests, studies, and measurements performed in order to evaluate compliance to hygiene standards, there are many direct measurements of physical factors, such as acoustic noise and vibration. Over recent years there has been an upward trend in the number of those [5].
Conducting ILCs when measuring physical factors, affecting humans in their living environment, such as acoustic noise and vibration, has a number of features. The main feature is that the object, the properties of which are being measured in the laboratory, cannot be sent to participants for measurement. Working place and residential development area can be considered the examples of such objects. Thus, the model objects are used for proficiency testing (OPT). It therefore seems necessary to perform ILC at the premises of provider ensuring availability of OPT and stability of OPT parameters. The other feature of noise and vibration measurement is impossibility of simultaneous measurement of one object by 
several laboratories, i.e. impossibility of conducting ILCs with the use of parallel programs. That is why the ILC providers use sequential programs with sequential access to OPT being the source of the measured factor. Meanwhile, the measured OPT parameters stability is controlled by reference laboratory [6] authorized by ILC provider.

Such practice of ILCs has been carried out since 2016 within the framework of the PHYSFACTOR-TEST voluntary certification system, as well as by other ILC providers [7, 8]. The method for carrying out and arranging ILCs when performing direct measurements has been reported [9].

The presence of OPT with appropriate characteristics is a key requirement to performing ILC using the approach described above.

Both natural and model objects may be used as OPTs. The model objects' assessed parameters stability is ensured by specialized test benches (TBs).

When performing ILCs involving measurement of acoustic noise and vibration, it is difficult to use natural objects due to low stability, unpredictability of parameter changes during measurement, and impossibility of setting specific parameters.

The study was aimed to summarize the approaches to creation and the practice of using OPT based on physical simulation of acoustic noise sources, airborne ultrasound, and vibration for ILC, as well as to assess the effectiveness of using the TB developed as an OPT for ILC with measurement of acoustic noise and vibration.

\section{METHODS}

Analysis of the effectiveness of OPTs based on physical simulation of factors, the test benches (TB), was carried out based on the results of TB testing and standardization, as well as the results of ILCs performed with the use of those.

The basic requirements for TB are as follows:

- the level of the factor generated should be in the range from the value three times (or by $10 \mathrm{~dB}$ ) exceeding the detection threshold of the measurement systems, most commonly used by laboratories, to the level around the threshold limit value;

- parameters of the studied feature (hereinafter the factor) should remain stable for at least 20-60 min;

- susceptibility of TB performance to environmental factors should be kept to a minimum; there should also be a possibility of considering the impact of these factors;

- it is necessary to ensure carrying out ILCs by all participants by way of a sequential access to TB;

- it is necessary to take into account the measurement technique (direct measurement method) and the features of using the measurement system;

- TB should adequately simulate the impact of the measured factor on the environment (working place, working area);

- when constructing TB, it is necessary to strike a balance between thorough simulation of the factor impact on environmental objects and ensuring the stability and reproducibility of measurements;

- TB should enable setting various modes and factor intensities;

- TB should ensure reproducibility of levels being monitored when performing repeated measurements during the TB operation in the course of ILC;

- when using TB, it is necessary to ensure resistance to externally acting interfering influences (interference immunity).

The results of using TB as an OPT were treated based on the following factors:

- acoustic noise;
- airborne ultrasound;

- local vibration;

- general machinery and household appliances vibration.

ILCs and measurements in the course of TB testing were carried out in accordance with the previously developed programs using the methods that had successfully passed metrological standardization. The ILC participants knew in advance the documents and were provided additional training prior to ILC.

All measurements were performed using the following measurement devices:

- Ecophysika-110A system (OCTAVA-ElectronDesign; Russia);

- AK-1000 acoustic calibrator (OCTAVA-ElectronDesign; Russia);

- KB-160 portable vibration reproducing device (vibrocalibrator) (OCTAVA-ElectronDesign. Russia).

\section{RESULTS}

Acoustical noise was the first type of ILC of physical factors. Currently, distribution of acoustic signal record as a reference for proficiency testing is being widely practiced. However, first, under this approach it could not be said that OPT is the same object the laboratory investigates. According to their areas of accreditation, laboratories perform measurements on various environmental objects (working areas, human living environment) or equipment testing. Under the approach discussed above, OPT is a speaker or digital recording; second, such approach in its current form has outlived its purpose and does not enable us to judge the ILC participant proficiency due to impossibility to perform quantitative comparison of the measurement results with the reproduced value. Furthermore, the content of measurement tasks does not comply with the changed regulatory framework.

In order to ensure interlaboratory comparison, we constructed TBs, playing back the noise with high stability. TBs consisted of waveform generator, power amplifier, and highquality full-range speaker. In order to assess the short-term stability, we used the reproduced by TB noise parameters of the model OPT, averaged during direct measurement. During the short periods, corresponding to typical ILC duration (up to $120 \mathrm{~min}$ ), this parameter varied within the limit of $\pm 0.5 \mathrm{~dB}$, which provided the short-term TB stability appropriate for ILC. Within the interval of several months with the same settings, the noise level reproduced by TB varied within the limit of \pm $2 \mathrm{~dB}$, which provided the long-term stability appropriate for continuous operation of TB.

The area of the facility, in which the measurement is performed, should be at least $40 \mathrm{~m}^{2}$, and the minimum linear size of the facility should be at least $2.5 \mathrm{~m}^{2}$. Standard room environment conditions for temperature, humidity, pressure, and air velocity should be maintained.

Test points should be selected $1 \mathrm{~m}$ away from the sound source at a height of $1.5 \mathrm{~m}$ from the surface of the floor. The reference point should be no closer than $1 \mathrm{~m}$ from the walls, window and door openings. Depending on the number of measured noise parameters and measurement program, the number of reference points may vary between 1 and 4 .

Sensitivity of sound level meter (measurement system) was tested prior to measurement. The testing was performed in accordance with the sound level meter user guide. Sensitivity test was carried out using class 1 acoustic calibrator by GOST IEC 60942 having the verification certificate and approved by the sound level meter manufacturer.

During the measurements, the acoustic level (acoustic pressure) of background noise should be different from 
the acoustic level (acoustic pressure), provided by operating source, by not less than $10 \mathrm{~dB}$. There should be no random noise in the facility.

The test duration was at least $1 \mathrm{~min}$, and the number of measurements for each reference point was at least 3.

Measurement accuracy in accordance with the method used $[10,11]$ is characterized by expanded uncertainty of measurements with a coverage factor of 2, corresponding to 95\% confidence interval. Expanded uncertainty of measured acoustic level with the method applied does not exceed $1.2 \mathrm{~dB}$, and the expanded uncertainty of measured acoustic pressure does not exceed $2.2 \mathrm{~dB}$.

More than 150 interlaboratory comparisons have been carried out.

Performing ILC with the acoustic level (acoustic pressure) measurement using the discussed TB met the need for correct comparison of the results obtained by the ILC participants and the reference laboratory, as well as for adequate simulation of the real world conditions of acoustic noise measurement at the working place or other object. The proposed ILC method made it possible to set different levels for the factor to be measured. When conducting measurement, it is necessary to maintain the conditions required for prevention of erroneous results.

ILC with the airborne ultrasound level measurement was performed the same way. Design of TB, being the object for proficiency testing, was almost the same, however, the frequency of the acoustic signal played back was within the range of 11-22 kHz. High-frequency transducer with high pass filter having a cut-off frequency of $7-9 \mathrm{kHz}$ was used to play back ultrasound signals.

TB simulated the source of airborne ultrasound at the working place. The 1/3-octave-band acoustic pressure level was measured. TB made it possible to achieve the acoustic pressure levels of up to 85-87 dB.

The requirements for conducting measurements are generally the same as for acoustic noise parameters measurement. However, the important factor affecting the measurement results is pointing the sound level meter microphone at the source of ultrasound signal. In some microphones, it is necessary to consider the parameter adjustment for ultrasonic frequency range.

All acoustic measurements during ILC were performed with the microphone fixed in the reference point with a rack.

Interlaboratory comparisons, when vibration is measured by testing laboratories, are no less urgent and much more complex in terms of arranging and conducting. The measurement results are influenced by numerous factors: vibration source stability resulting from its design and operating mode, type

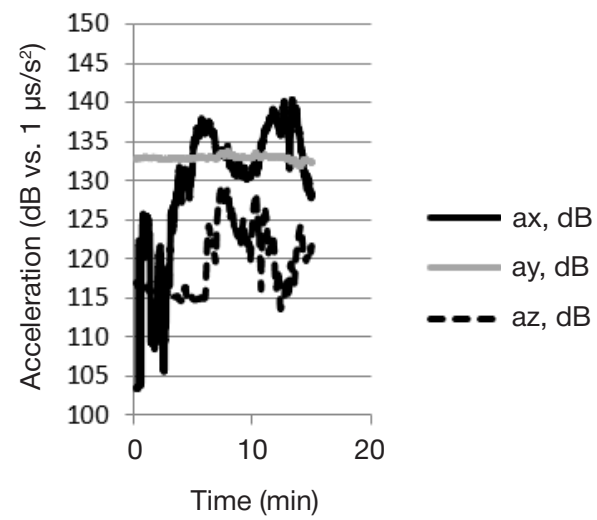

Vibration level with no feedback

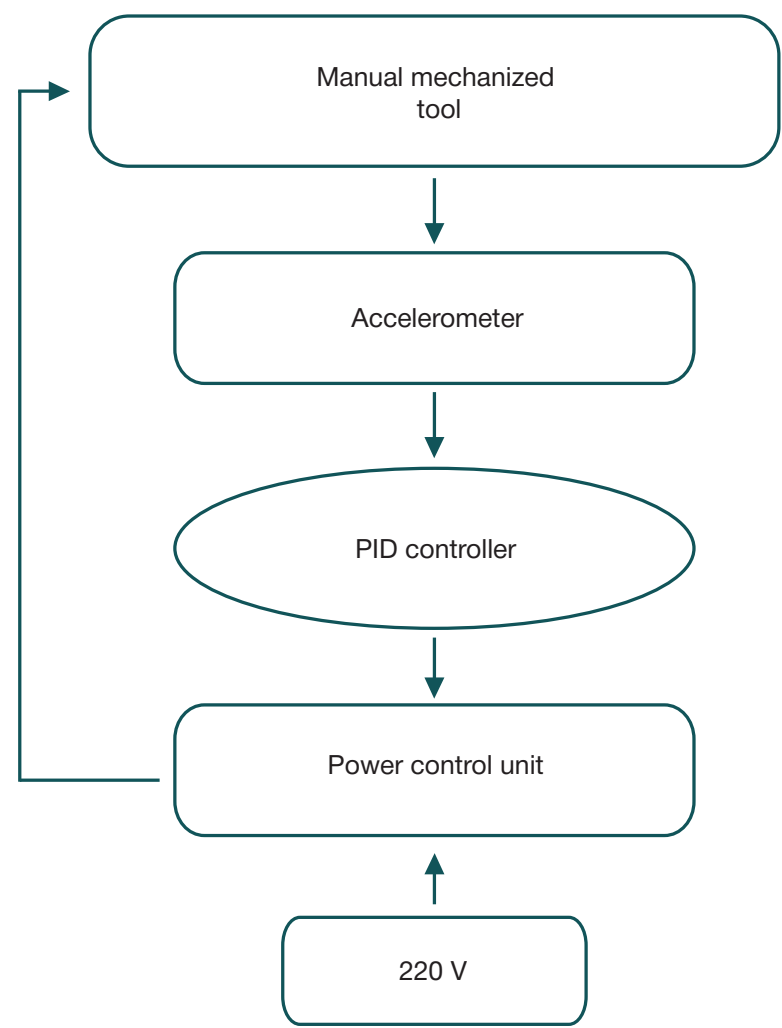

Fig. 1. Flow chart for the physical model of TB for local vibration OPT with automated maintenance of specified vibration acceleration level

and quality of the measurement system transducer fastening, mechanical interaction of the "worker-instrument-processed object" system, etc. That is why vibration measurement during simple simulation of the working process with the use of manual mechanized tool by the user would result in sharp discontinuities in the results, i.e. actually, there no short-term and long-term stability of measurements would be observed. This would make it difficult to compare these during interlaboratory comparisons. In addition, the user would be adversely affected by vibration. Even greater difficulties can be expected while ensuring measurement of general vibration, provided mostly by massive equipment and transport.

The circumstances described above have made it necessary to develop TBs that could be used as a part of OPT to measure the general vibration levels during ILCs.

Initially, the possibility of measuring local vibration with an instrument in idle or eccentric loading mode was studied.

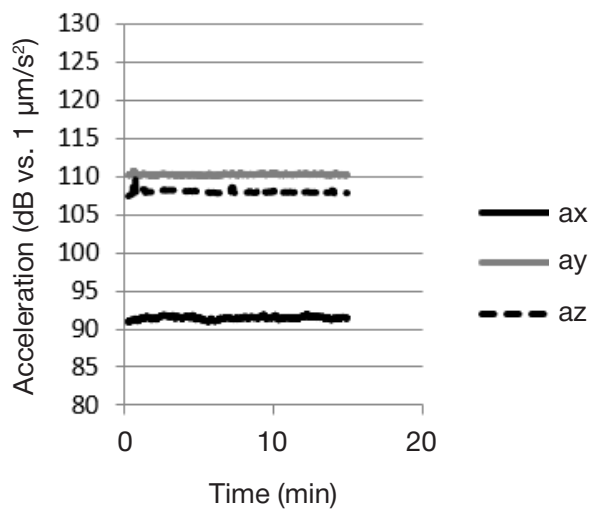

Vibration level with feedback

Fig. 2. Multifunction tool vibration levels with the specified vibration acceleration level maintenance system off and on 
However, in this case, stability proved insufficient. Thus, TB with automated specified mechanized tool vibration level maintenance using the proportional integral derivative (PID) controller was designed (Fig. 1). Multifunction tool or drilling machine supported by hanger (bracing) was used as a manual mechanized tool.

The results of comparative vibration level measurements in the presence and absence of feedback are presented in Fig. 2.

The data presented demonstrate that the system with feedback shows much more stable levels of local vibration generated for vibration acceleration. This justifies the increased complexity of TB for ILCs with measurement of local vibration.

To date, over 100 interlaboratory comparisons with the use of discussed TB have been performed.

When performing ILC with measurement of local vibration, a three-component vibration sensor was fixed on the instrument handle with a cubicle adapter in accordance with GOST 31192.2 [12]. Sensitivity axes of the vibration sensors were oriented in the $Z, X$ and $Y$ directions in accordance with the basicentric coordinate system of the human hand doing the work [13]. The absence of interference caused by electromagnetic fields and sensor cable movement were checked prior to measurement. Microclimatic conditions were consistent with the measurement system operation conditions.

The measurement was performed during a number of observation periods. At least four measurements of adjusted acceleration for each direction in each reference point were performed during each observation period. The duration of each test was at least $15 \mathrm{~s}$.

Measurement accuracy in accordance with the method used [14] is characterized by expanded uncertainty of measurements with a coverage factor of 2, corresponding to 95\% confidence interval. Expanded uncertainty of measurements performed using the method does not exceed $3.8 \mathrm{~dB}$.

TB made it possible to achieve the level of vibration acceleration up to $135 \mathrm{~dB}$.

The reported approach to performing ILC with the use of TB to generate stable vibration met the need for correct comparison of the results obtained by the ILC participants and the reference laboratory, as well as for adequate simulation of the real world conditions of local vibration measurement at the working place. The designed TB made it possible to set various levels of the factor to be measured, and ensured stable vibration generation.

A number of testing laboratories need to perform interlaboratory comparisons when measuring general machinery or household appliances vibration. Hygienic characteristics and standards of general machinery vibration, as well as the procedure of general machinery vibration measurement, differ from those of local vibration. General machinery vibration and household appliances vibration are the low-frequency vibration types, and are measured with the use of adapter, for example the floor standing platform mounted on the surface, on which the measurement is performed.

It is extremely difficult to perform ILCs with the measurement of general vibration on the basis of the physical object, therefore, it was necessary to develop the TB simulating the general vibration source. Such TB was developed. It was a platform sized $300 \times 300 \mathrm{~mm}$ with a $3000 \mathrm{rpm}$ electric motor fastened from below. The electric motor was operated in the eccentric loading mode, which resulted in vibration of the bench. In order to ensure stability and set the level of vibration acceleration, electric motor was included in the automatic control loop with vibration acceleration feedback, as described above. When performing measurement, the measurement system accelerometer was mounted on the platform surface. The platform itself was placed on a shock absorbing material.

TB made it possible to achieve vibration acceleration levels of up to $130 \mathrm{~dB}$. During TB standardization, it was found that the average level of general vibration generated (Z-axis $-L z)$ depending on the frequency $(F)$ was as follows:

\begin{tabular}{|c|c|}
\hline $\mathrm{F}, \mathrm{Hz}$ & $\mathrm{Lz}, \mathrm{dB}$ \\
\hline 4 & 60,1 \\
\hline 8 & 81,6 \\
\hline 16 & 103,1 \\
\hline 31,5 & 109,4 \\
\hline 64 & 94,5 \\
\hline
\end{tabular}

Thus, maximum energy of vibration acceleration was observed in octave bands of 16 and $31.5 \mathrm{~Hz}$, which was typical of general or household appliances vibration. For instance, such range corresponds to vibration induced by subway trains, and the $20-50 \mathrm{~Hz}$ frequency vibration is common to numerous industrial sources of general vibration.

Vibration acceleration was measured for 6 days, 4-6 measurements with test duration of $5 \mathrm{~min}$. It was found, that during the entire observation period the measured equivalent vibration acceleration levels fluctuated in the following way: for $X$-axis within the limit of $0.7 \mathrm{~dB}$; for $Y$-axis within the limit of $2.3 \mathrm{~dB}$, and for $Z$-axis within the limit of $1.0 \mathrm{~dB}$. During one measurement session, the measured vibration acceleration fluctuations did not exceed $0.2 \mathrm{~dB}$ for $X$-axis, 0.6 for $Y$-axis, and $0.5 \mathrm{~dB}$ for $Z$-axis, which indicated the short-term stability of measurements appropriate for ILC.

Thus, TB designed for ILCs with measurement of general vibration factor ensures adequate simulation of the real world conditions of the general vibration measurement and makes it possible to perform measurements with sequential ILC participants' access to TB. The use of discussed TB would enable correct comparison of the general vibration measurement results obtained by the ILC participants, and the reference laboratory. TB has been already introduced into the work of the ILC coordinator acting under the authority of the PHYSFACTOR-TEST voluntary certification system.

In case of small discontinuity of measured vibration acceleration values the expanded uncertainty can be calculated by classifying general vibration measurements as single measurements [15].

\section{DISCUSSION}

Currently, simulation of technological processes and situation at environmental objects is quite common for measurement of standardized physical factors. Therefore, the development and application of noise source physical models for the purposes of ILC are consistent with the established practice of such factors' measurement. The need for such simulation for the purposes of ILC results from the requirements for OPT.

TBs described in this report ensure adequate simulation of acoustic noise sources at the working place and other environmental objects, and make it possible to ensure interlaboratory comparisons for all the methods applied for acoustic noise and vibration parameter measurement.

TBs contained microcontroller vibration agitator controls with feedback, which provided appropriate stability of the generated local and general vibration.

The methods developed specifically for ILCs play a crucial role in arranging and conducting ILCs. The use of standardized 
measurement methods makes it possible to take into account all the conditions affecting the measurement results, and provide metrologically traceable measurements during ILC [10, 11, 14]. The measurement of acoustic pressure in the ultrasonic range and general vibration acceleration is performed as direct measurement in accordance with the ILC programs, however, the methods for measuring these factors are planned to be developed and standardized.

The ILC results are evaluated based in the $\mid$ En| criterion [6, 16], which ensures objectiveness of the judgment about the participating laboratory proficiency.

When performing ILC, it is possible to evaluate both the measurement results and the compliance with measurement procedure, which can be also used to assess the participants' proficiency.

\section{References}

1. Obshhie trebovanija $\mathrm{k}$ kompetentnosti ispytatel'nyh i kalibrovochnyh laboratorij GOST ISO/IEC 17025-2019. M.: Standartinform, 2019. Russian.

2. Ob utverzhdenii Kriteriev akkreditacii, perechnja dokumentov, podtverzhdajushhih sootvetstvie zajavitelja, akkreditovannogo lica kriterijam akkreditacii, i perechnja dokumentov $v$ oblast standartizacii, sobljudenie trebovanij kotoryh zajaviteljami, akkreditovannymi licami obespechivaet in sootvetstvie kriterijam akkreditacii. Prikaz Minjekonomrazvitija Rossii ot 30 maja 2014 g. Dostupno po ssylke: http://base.garant.ru/707/2358/ (data obrashhenija: 05.12.2016). Russian.

3. Ob utverzhdenii Polozhenija o sostave svedenij o rezul'tatah dejatel'nosti akkreditovannyh lic, ob izmenenijah sostava in rabotnikov i o kompetentnosti jetih rabotnikov, ob izmenenijah tehnicheskoj osnashhennosti, predstavljaemyh akkreditovannymi licami v Federal'nuju sluzhbu po akkreditacii, porjadke srokah predstavlenija akkreditovannymi licami takih svedenij $v$ Federal'nuju sluzhbu po akkreditacii. Prikaz Minjekonomrazvitija Rossii ot 30 maja 2014 g. \# 329. Dostupno po ssylke: http://docs. cntd.ru/document/420203445 (data obrashhenija: 12.06.2020). Russian.

4. Politika Rosakkreditacii $v$ otnoshenii proverki kvalifikacii putem provedenija mezhlaboratornyh slichitel'nyh (sravnitel'nyh) ispytanij, utverzhdena rukovoditelem Federal'noj sluzhby po akkreditacii 28.10.2016. Dostupno po ssylke: http://docs. cntd.ru/document/456085241 (data obrashhenija: 12.06.2020) Russian.

5. O sostojanii sanitarno-jepidemiologicheskogo blagopoluchija naselenija v Rossijskoj Federacii v 2018 godu. Gosudarstvenny] doklad [Jelektronnyj resurs]. Dostupno po ssylke: https://www. rospotrebnadzor.ru/upload/iblock/798/gosudarstvennyy-doklado-sostoyanii-sanitarno_epidemiologicheskogo-blagopoluchiyanaseleniya-v-rossiyskoy-federatsii-v-2018-godu.pdf (data obrashhenija: 12.06.2020). Russian.

6. Ocenka sootvetstvija. Osnovnye trebovanija $\mathrm{k}$ provedeniju proverki kvalifikacii GOST ISO/IEC 17043-2013. Dostupno po ssylke: https://files.stroyinf.ru/Data2/1/4293774/4293774569.pdf (data obrashhenija: 12.06.2020). Russian.

7. Centr mezhlaboratornyh sravnitel'nyh ispytanij SDS FIZFATORTEST https://www.octava.info/interlaboratory_comparison. Dostupno
According to the comments of the participants, participation in the ILCs in accordance with the discussed technology is of great importance in terms of self-esteem and personal proficiency improvement.

\section{CONCLUSION}

Rationale for technology of acoustic noise source physical simulation, used as an object for proficiency testing during the interlaboratory comparisons, has been provided. The test benches developed meet the desired characteristics of the objects for proficiency testing, and adequately simulate the conditions at the working places and other environmental objects. When verifying the laboratory proficiency, it is necessary to assess both measurement results and measurement procedure. po ssylke: https://files.stroyinf.ru/Data2/1/4293774/4293774569. pdf (data obrashhenija: 12.06.2020). Russian.

8. Plan provedenija mezhlaboratornyh slichitel'nyh ispytanij provajdera UNIIM - filial FGUP «VNIIM im. D.I. Mendeleeva» na 2020 god. Dostupno po ssylke: https://uniim.ru/planmsi2020/ (data obrashhenija: 12.06.2020). Russian.

9. Semjonov SYu, Sterlikov AV, Tananykin NI, Kolbutova KB, Kurilenko YuV, Voronkov AA. Vneshnij kontrol' kachestva issledovanij $v$ ispytatel'nyh laboratorijah pri provedenii prjamyh izmerenij. Medicina jekstremal'nyh situacij. 2018; 20 (2): 223-30. Russian.

10. Metodika izmerenij urovnej zvuka i zvukovogo davlenija izluchenija istochnikov zvuka MI NPF-15-032 (FR. 1.36.2016.23826). OOO «NPF JelektronDizajn». M., 2015; 15 s. Russian.

11. Metodika izmerenij urovnej zvuka i zvukovogo davlenija izluchenija istochnikov zvuka MI NPF-17-032 (FR. 1.36.2017.26200). OOO NPF «JelektronDizajn». M., 2017; 15 s. Russian.

12. Vibracija. Izmerenie lokal'noj vibracii i ocenka ee vozdejstvija na cheloveka. Chast' 2. Trebovanija k provedeniju izmerenij na rabochih mestah, GOST 31192.2-2005. Dostupno po ssylke: http://docs.cntd.ru/document/1200060914 (data obrashhenija: 12.06.2020). Russian.

13. Gigienicheskie normativy i trebovanija k obespecheniju bezopasnosti i (ili) bezvrednosti dlja cheloveka faktorov sredy obitanija. SanPiN 1.2.3685-21. Dostupno po ssylke: https://docs. cntd.ru/search?q=\%D0\%A1\%D0\%B0\%D0\%BD\%D0\%9F\%D0 \%B8\%D0\%9D\%201.2.3685-2 (data obrashhenija: 10.06.2021). Russian.

14. Metodika izmerenij vibracii ruchnoj mashiny, MI NPF-16-033. 000 «NPF JelektronDizajn». M., 2016; 18 s. Russian.

15. Izmerenija prjamye odnokratnye. Ocenivanie pogreshnostej neopredelennosti rezul'tata izmerenij R 50.2.038-2004 Gruppa T80. Rekomendacii po metrologii. Dostupno po ssylke: http:// docs.cntd.ru/document/1200037562 (data obrashhenija: 12.06.2020). Russian.

16. Statisticheskie metody. Primenenie pri jeksperimental'noj proverke kompetentnosti posredstvom mezhlaboratornyh sravnitel'nyh ispytanii, GOST R 50779.60-2017 (ISO 13528:2015). Dostupno po ssylke: https://docs.cntd.ru/document/1200146875 (data obrashhenija: 10.06.2021). Russian.

\section{Литература}

1. Общие требования к компетентности испытательных и калибровочных лабораторий ГОСТ ISO/IEC 17025-2019. М.: Стандартинформ, 2019.

2. Об утверждении Критериев аккредитации, перечня документов, подтверждающих соответствие заявителя, аккредитованного лица критериям аккредитации, и перечня

документов в области стандартизации, соблюдение требований которых заявителями, аккредитованными лицами обеспечивает их соответствие критериям аккредитации. Приказ Минэкономразвития России от 30 мая 2014 г. Доступно по ссылке: http://base.garant.ru/70712358/ (дата обращения: 05.12.2016). 
3. Об утверждении Положения о составе сведений о результатах деятельности аккредитованных лиц, об изменениях состава их работников и о компетентности этих работников, об изменениях технической оснащенности, представляемых аккредитованными лицами в Федеральную службу по аккредитации, порядке и сроках представления аккредитованными лицами таких сведений в Федеральную службу по аккредитации. Приказ Минэкономразвития России от 30 мая 2014 г. № 329. Доступно по ссылке: http://docs. cntd.ru/document/420203445 (дата обращения: 12.06.2020).

4. Политика Росаккредитации в отношении проверки квалификации путем проведения межлабораторных сличительных (сравнительных) испытаний, утверждена руководителем Федеральной службы по аккредитации 28.10.2016. Доступно по ссылке: http://docs.cntd.ru/ document/456085241 (дата обращения: 12.06.2020).

5. О состоянии санитарно-эпидемиологического благополучия населения в Российской Федерации в 2018 году. Государственный доклад [Электронный ресурс]. Доступно по ссылке: https://www.rospotrebnadzor.ru/upload/ iblock/798/gosudarstvennyy-doklad-o-sostoyanii-sanitarno epidemiologicheskogo-blagopoluchiya-naseleniya-v-rossiyskoyfederatsii-v-2018-godu.pdf (дата обращения: 12.06.2020).

6. Оценка соответствия. Основные требования к проведению проверки квалисиикации ГOCT ISO/IEC 17043-2013. Доступно по ссылке: https://files.stroyinf.ru/Data2/1/4293774/4293774569. pdf (дата обращения: 12.06.2020).

7. Центр межлабораторных сравнительных испытаний СДС ФИЗФАТОР-ТЕСТ https://www.octava.info/interlaboratory comparison. Доступно по ссылке: https://files.stroyinf.ru/ Data2/1/4293774/4293774569.pdf (дата обращения: 12.06.2020).

8. План проведения межлабораторных сличительных испытаний провайдера УНИИМ - филиал ФГУП «ВНИИМ им. Д.И. Менделеева" на 2020 год. Доступно по ссылке: https://uniim. ru/planmsi2020/ (дата обращения: 12.06.2020).
9. Семёнов С. Ю., Стерликов А. В., Тананыкин Н. И., Колбутова К. Б., Куриленко Ю. В., Воронков А. А. Внешний контроль качества исследований в испытательных лабораториях при проведении прямых измерений. Медицина экстремальных ситуаций. 2018; 20 (2): 223-30.

10. Методика измерений уровней звука и звукового давления излучения источников звука МИ НПФ-15-032 (ФР. 1.36.2016.23826). ООО «НПФ ЭлектронДизайн». М., 2015; 15 с.

11. Методика измерений уровней звука и звукового давления излучения источников звука МИ НПФ-17-032 (ФР 1.36.2017.26200). ООО НПФ «ЭлектронДизайн». М., 2017; $15 \mathrm{c}$.

12. Вибрация. Измерение локальной вибрации и оценка ее воздействия на человека. Часть 2. Требования к проведению измерений на рабочих местах, ГОСТ 31192.2-2005. Доступно по ссылке: http://docs.cntd.ru/document/1200060914 (дата обращения: 12.06.2020).

13. Гигиенические нормативы и требования к обеспечению безопасности и (или) безвредности для человека факторов среды обитания. СанПиН 1.2.3685-21. Доступно по ссылке: https://docs.cntd.ru/search?q=\%D0\%A1\%D0\%B0\%D0\%BD\% D0\%9F\%D0\%B8\%D0\%9D\%201.2.3685-2 (дата обращения: 10.06.2021).

14. Методика измерений вибрации ручной машины, МИ НПФ-16033. ООО «НПФ ЭлектронДизайн». М., 2016; 18 с.

15. Измерения прямые однократные. Оценивание погрешностей и неопределенности результата измерений Р 50.2.0382004 Группа Т80. Рекомендации по метрологии. Доступно по ссылке: http://docs.cntd.ru/document/1200037562 (дата обращения: 12.06.2020).

16. Статистические методы. Применение при экспериментальной проверке компетентности посредством межлабораторных сравнительных испытаний, ГОСТ Р 50779.60-2017 (ИСО 13528:2015). Доступно по ссылке: https://docs.cntd.ru/ document/1200146875 (дата обращения: 10.06.2021). 